\title{
乾燥茶葉微粉砕殺菌・乾燥微粉末食材殺菌装置の開発*
}

\author{
藤田浩三 $^{* 1}$, 高倉章雄 ${ }^{* 1}$
}

\section{Development of New Non-Heating Sterilizer for Dried Micropowder Foods}

\author{
Kouzou FUJITA*1 and Norio TAKAKURA \\ ${ }^{* 1}$ Kyoto Institute of Technology. Dept. of Mechanical Engineering, \\ Gosho-Kaido-cho, Matsugasaki, Sakyo-ku, Kyoto, 606-8585, Japan
}

For non-heating sterilization, the use of various radiations including gamma-ray irradiation has been approved in the United States, Europe, and China, whereas legally prohibited from the safety perspective in Japan. Previously we reported the development of a fine grinder for dry tea leaves, implying the occurrence of sterilizing activity that has not been found in conventional grinding procedures. The present study aimed to elucidate the mechanism of occurrence of sterilizing activity in the use of the developed apparatus "Batch-type Vertical Rotation Planetary Ball Mill (VPBM)" and to realize a non-heating sterilizer for Dried micro powder foods. First, a method of enhancing sterilization was devised and successfully tested in a validation experiment. Subsequently, the generation of ultraviolet rays by the enhancing method and enhanced sterilization were assumed and verified in a qualitative validation experiment. As the wavelength of relaxation frequency on the gradual extinction of electronic polarization, a dielectric polarization, is within the range from visible rays to ultraviolet rays, it was hypothesized that if similar phenomena (generation and gradual extinction of electronic polarization) occur in the VPBM-specific crushing mechanism, ultraviolet rays may be most probably generated from dried capsules and cell walls of bacteria. Thus, final validation experiments were carried out on dried and pulverized food materials containing a lot of bacteria, with favorable results. Mechanical energy may have been converted into electric energy, then to chemical energy for non-heating sterilization.

Key Words : Non-Heating Sterilization, VPBM, Dried Micro Powder Foods, Ultraviolet Rays, Relaxation Frequency, Crushing Mechanism, Electronic Polarization, Dried Capsules and Cell Walls of Bacteria, Mechanical Energy, Chemical Energy

\section{1. 緒 言}

近年, 啫好性食品や健康食品などの機能性食品志向に伴って粉末状食品の開発が進み，その市場が拡大している. これらの食品の衛生面での安全確保には, 一般に加熱殺菌処理が施されている. 粉末は重量当たりの表面積が極めて 広く全表面を均等に加熱することは技術的に難しいために，加熱殺菌処理として，(1)原材料を粉砕前に加熱する，(2) 粉砕後の粉末を気流式過熱水蒸気で加熱する方法が主に用いられている. 粉砕前に加熱する例として, 抹茶の原材料 である生茶葉は入口温度 $200^{\circ} \mathrm{C}$, 出口温度 $100^{\circ} \mathrm{C}$ 加熱炉の中を約 30 分かけて移動する間に乾燥と殺菌処理がなされ

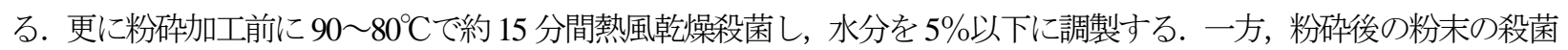
で現在最も多く実用に用いられる気流式過熱蒸気殺菌装置では, 加熱温度 $130 \sim 150^{\circ} \mathrm{C}$, 気流速度 $30 \mathrm{~m} / \mathrm{s}$ で, 粉末食材 を浮遊・拡散して, 短時間 4 秒で殺菌を完了寸る. しかし, これらの粉砕前および粉碀後の加熱殺菌では, 粉砕加工 工程での細菌の侵入・増殖，および粉末食材には熱の影響による官能品質（味・色・香り）の低下が避けられない.

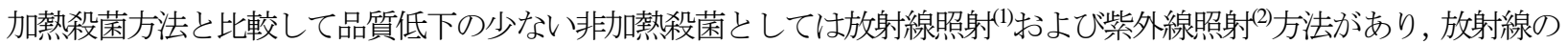

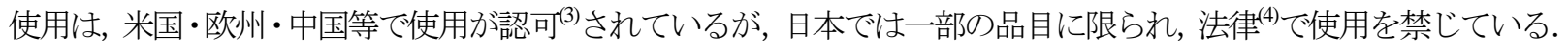
また，紫外線の使用は，例えば医療用容器や空気中のごく微量の粉鹿に波長 $260 \mathrm{~nm} ・$ 線量 $10 \sim 25 \mathrm{~mW} ・ \mathrm{~s} / \mathrm{cm}^{2}$ で照射し て殺菌が行われているが，粉末食材に適用できる実用装置は開発されていない，このことから，粉末状食材の品質低

\footnotetext{
* 原稿受付 2011 年 9 月 15 日

*1 正員，京都工芸繊維大学（

E-mail: info@fujimill.co.jp
} 
下を抑制できる安全性の高い殺菌技術の開発が望まれている.

筆者らは，これまで抹茶製造用乾燥茶葉粉砕装置（バッチ型垂直回転遊星ボールミル）の開発を行ってきた。この 装置において, 食品衛生基準以上に多量に一般細菌を含む茶葉を用いて粉砕前後の一般細菌数の変化を検査したとこ ろ，粉砕後に一般細菌が $1 / 5$ 程度に減少することが確認された。このような，粉砕加工時における減菌現象は従来の 食材粉砕装置では全くみられない事象である，そこで，本研究では，バッチ型垂直回転遊星ボールミルでの乾燥茶葉 の粉砕時における細菌減少の発現メカニズムを明らかにし, 非加熱方式の乾燥微粉末食材殺菌装置の開発を試みた.

\section{2. 開発装置の減菌現象}

\section{$2 \cdot 1$ バッチ型垂直回転遊星ボールミルの概略}

バッチ型垂直回転遊星ボールミル及びバッチ容器（以下ミルポット）の概略構造をそれぞれ図 1 ・図 2 (蓋の図を省

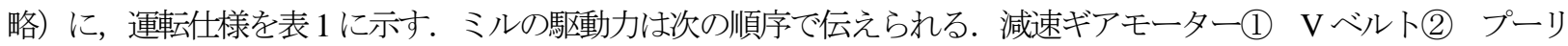

(3) 公転主軸(4) ディスク（5) 自転軸(6) 自転用スプロケット(7) 自転用チェン（8) 固定スプロケット(9) ミルポッ トホルダー10 ミルポット(11). ミルポットは，公転しながらミルポット軸の周りを自転し，回転面は鉛直である．運 転時には，ミルポットはミルポットホルダーの装着部位にボルトで固定される．また，装置にはミルポットをアース するための可動接点12 とタイマースイッチ13が設置されている. なお，この装置の抹茶生産能力は石的の約 20 倍であ り，石臼で製造した商品基準を満足する抹茶品質が得られる.

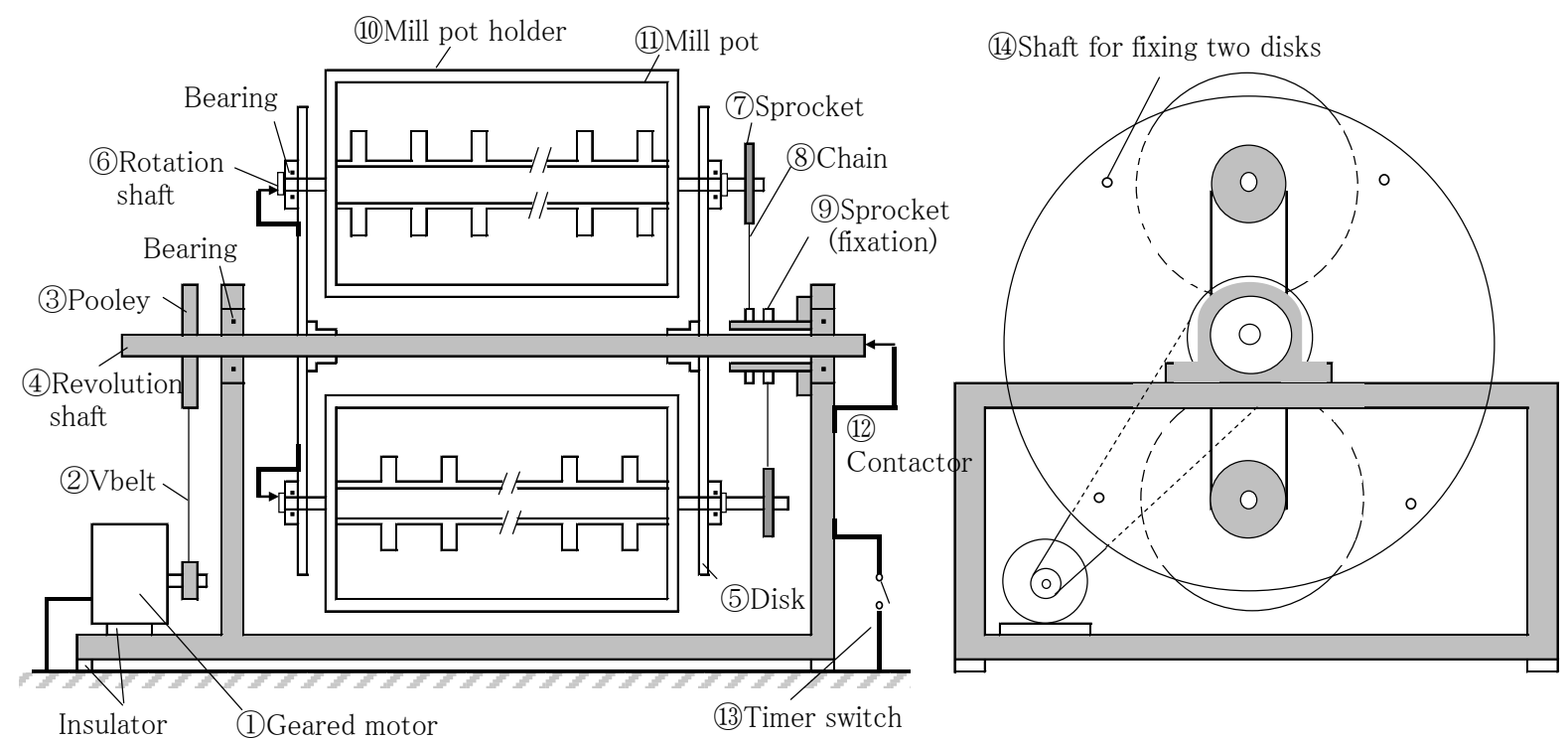

Fig.1 Schematic illustration of vertical planetary rotation ball mill

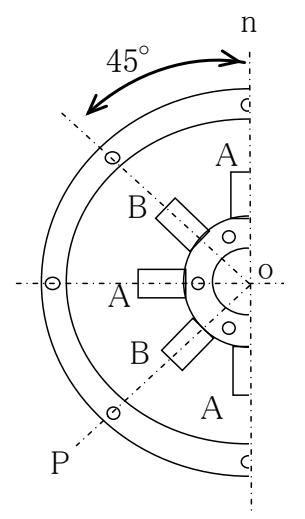

A arrangement

nop section

B arrangement

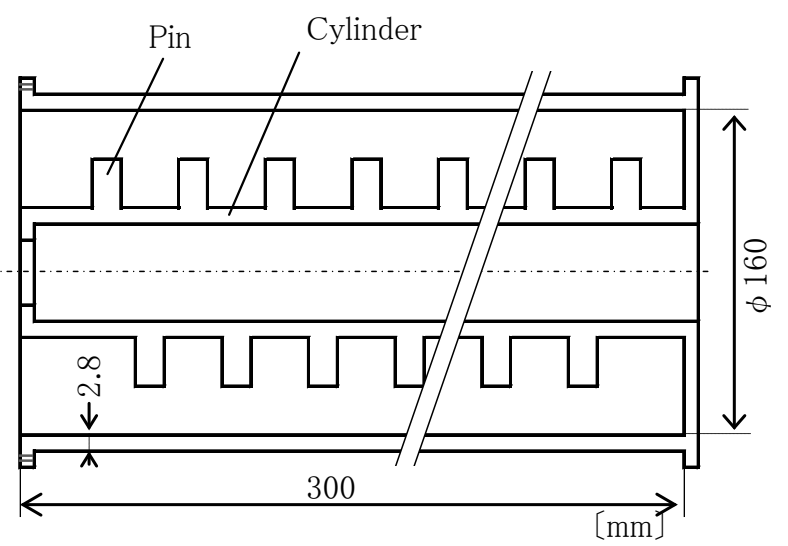

Fig.2 Mill pot with inner cylinder and pines 
Table 1 Specification

\begin{tabular}{|c|c||c|c|}
\hline Item & Specification & Item & Specification \\
\hline Mill pot type & Inner cylinder with pines & Required times & $40\lceil\mathrm{~min}]$ \\
\hline Steal ball weight per mill pot & $10.5\lceil\mathrm{~kg}]$ & Revolution frequency & $264[\mathrm{rpm}]$ \\
\hline Diameter of steal ball & $3\lceil\mathrm{~mm}]$ & Rotation frequency & $238\lceil\mathrm{rpm}]$ \\
\hline Tea weight per mill pot & $500\lceil\mathrm{~g}]$ & Cooling air temperature & Under $10\left[{ }^{\circ} \mathrm{C}\right]$ \\
\hline The number of mill pot & 2 & Power unit & $1.5 \mathrm{kw}$ Motor \\
\hline
\end{tabular}

\section{$2 \cdot 2$ 減菌現象}

食品衛生の観点から粉砕加工に伴う菌の増殖は厳禁であるため, 粉砕前の茶葉と粉砕後の抹茶の細菌数を調査した. なお，日本食品衛生法(5)では乾燥粉末食品に含まれる細菌は一般細菌数 3000 個/g 以下，大腸菌陰性と規定している.

\section{$2 \cdot 2 \cdot 1$ 通常粉砕後の減菌現象}

茶葉の粉砕加工前後 (粉砕時間 30 分) の菌数を測定した結果を表 2 に示す. ミルポットのアース有無のいずれにお いても粉砕加工後には菌の減少が確認された，表中の Kは，菌数の減少率である.

$$
\mathrm{K}=\frac{\text { 粉砕後の菌数 }}{\text { 粉砕前の菌数 }}
$$

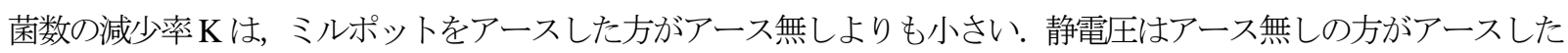
よりも高い. なお，粉砕加工時間を増加させても減少率 Kが減少するという傾向は見られなかった.

Table 2 Number of bacteria

\begin{tabular}{|c|c|c|c|}
\hline \multirow{2}{*}{$\begin{array}{c}\text { Mill pot with inner } \\
\text { cylinder and pines }\end{array}$} & \multicolumn{2}{|c|}{$\begin{array}{c}\text { Number of general bacteria/g } \\
\text { (Electrostatic maxvoltage }[\mathrm{kv}] \text { ) }\end{array}$} & \multirow{2}{*}{$\mathrm{K}$} \\
\cline { 2 - 3 } & Before the processing & After the processing & \\
\hline Electric earth & $2600(0)$ & $320(-43.1)$ & $1 / 8.1$ \\
\hline Electric nonearth & $2600(0)$ & $470(-56.8)$ & $1 / 5.5$ \\
\hline
\end{tabular}

\section{$2 \cdot 2 \cdot 2$ 減菌現象の復活}

粉砕加工後の抹茶は帯電し, 静電圧が零ではない状態である. そこで, 粉砕後の抹茶をアースされた金属容器に移 して自然除電し, 電荷・静電圧を零にして電気的に初期化して，この抹茶を再び粉砕加工を行った. 短時間の粉砕加 工において初回の粉砕時とほぼ同等の減少率 $\mathrm{K}$ 值が生じた. なお, 初回および再粉砕後の抹茶の静電圧はほとんど同 じであった. この菌数の減少傾向を明確にするために，食品衛生基準を超える多数の一般細菌を含んだ茶葉を用いて 粉砕(1) 一徐電一粉砕(2)の実験を行った. 粉砕(1)前後と再粉砕(2)後の結果を表 3 に示す.

Table 3 Bactericidal effect of mill

\begin{tabular}{|c|c|c|c|c|c|c|}
\hline \multirow{2}{*}{ Mode } & \multirow{2}{*}{$\begin{array}{l}\text { Material } \\
(500 \mathrm{~g})\end{array}$} & \multirow{2}{*}{$\begin{array}{c}\text { Mill pot with } \\
\text { inner cylinder and } \\
\text { pines }\end{array}$} & \multirow{2}{*}{$\begin{array}{l}\text { Mill time } \\
\text { [min] }\end{array}$} & \multicolumn{2}{|c|}{$\begin{array}{c}\text { Number of general bacteria /g } \\
\text { (Electrostatic maxvoltage }[\mathrm{kv}] \text { ) }\end{array}$} & \multirow{2}{*}{$\mathrm{K}$} \\
\hline & & & & $\begin{array}{l}\text { Before the } \\
\text { processing }\end{array}$ & $\begin{array}{l}\text { After the } \\
\text { processing }\end{array}$ & \\
\hline (1) & Tea leaves & Electric earth & 30 & $\begin{array}{c}25000 \\
(0)\end{array}$ & $\begin{array}{c}5300 \\
(-41.5) \\
\end{array}$ & $1 / 4.7$ \\
\hline (2) & Tea powder & " & 5 & $\begin{array}{c}5300 \\
(0)\end{array}$ & $\begin{array}{c}820 \\
(-39.4)\end{array}$ & $1 / 6.5$ \\
\hline
\end{tabular}

Means of bacteriological inspection. Standard plate count

Inspectional place. Laboratory of Public Health and Enviromental Chemistry, Kyoto Biseibutu Kenkyusho

\section{$2 \cdot 2 \cdot 3$ 結果と考察}

以上の結果から, 次のことが確認された. (1)バッチ型垂直回転遊星ボールミルによる粉砕加工中に茶葉・抹茶は帯 電する. (2減菌現象は粉砕加工初期に茶葉・抹茶が短時間に帯電する間に生じ, 茶葉・抹茶が帯電すると滅菌現象が 次第に減少する. (3抹茶を電気的に初期化することにより減菌現象が復活する. このことからミルポットをアースし た方がアースしない場合に比べ，減菌効果が大きいのは，茶葉・抹茶の電荷の一部分がアースにより除電されること によって, (3)の効果が作用したためと考えられる. なお，アースした場合に一般細菌が粉砕時間に伴って減少しない のは，帯電・除電による電荷・静電圧の変動が粉砕時間の増加に伴って減少するためであると推測される. 


\section{$2 \cdot 3$ 減菌現象の継続 $\cdot$ 強化}

ミルポットから抹茶・ボールを取り出し，除電・再粉砕を繰り返し行って減菌効果を高める方法は非効率・現実的 ではない. 粉砕加工中に減菌現象が継続できる方法が必要である. $2 \cdot 2 \cdot 3$ の考察からア一スの有無における茶葉・抹 茶の平均的な電荷・静電圧の推移を推測・仮定してそれを模式的に図 3 に示寸. 図において, 加工初期に茶葉・抹茶 の電荷・静電圧が急速に変動する時間を $\mathrm{Te}$ (アース有)・Tn (アース無) として，この時間以降はそれぞれの電荷・ 静電圧は準静的に推移寸るとし，また，実験結果から茶葉・抹茶の静電王 $\mathrm{V}$ は $|\mathrm{Ve}|$ （アース有）< $|\mathrm{Vn}|$ （アース無）と

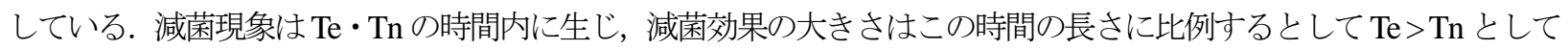
いる. なお，電荷 $\mathrm{C}$ はVV比例する(衴している.

\section{$2 \cdot 3 \cdot 1$ 強化案}

滅菌現象は, 電荷・静電圧が急速に変動する時間内に生ずると推測し電荷・静電圧の準静的状態を波動化する. 具 体的にはミルポットの非アースとアースを交互に操作する(クことにより, 図 3 に示すように茶葉・抹茶の電荷・静電 圧が $0 \rightarrow \mathrm{a}_{1} \rightarrow \mathrm{b}_{1} \rightarrow \cdots \cdots \mathrm{a}_{\mathrm{n}} \rightarrow \mathrm{b}_{\mathrm{n}}$ へと移行できれば減菌現象が継続すると考えた. そこでこの手法の効果を検証するた めに，非アースとアースの繰り返し回数と減菌効果の関係を調べた.

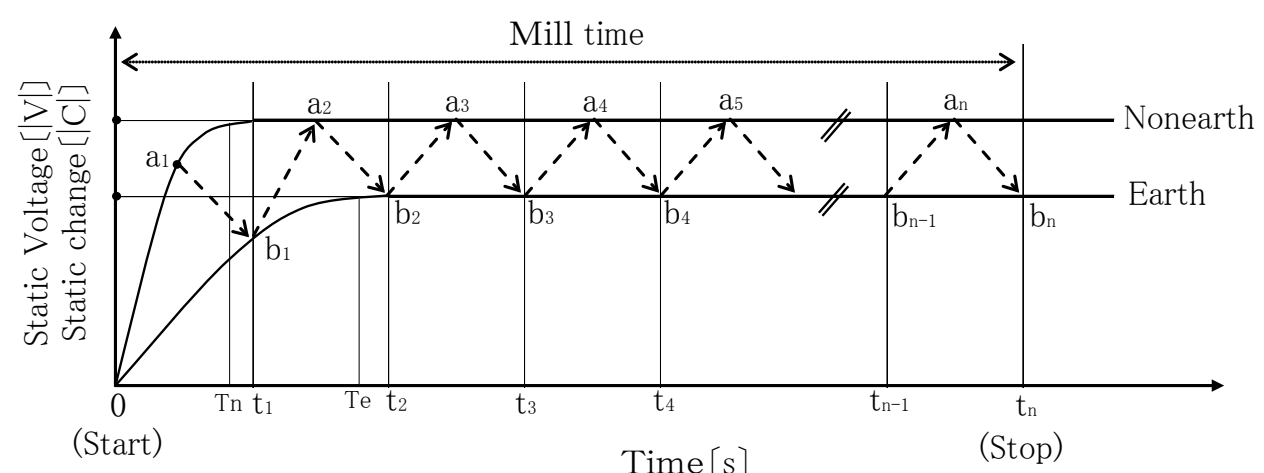

Fig.3 Average static voltage and change of particles in mill pot

\section{2・3·2 アース用タイマ一設置}

ミルポットの非アースとアースを粉砕加工中に複数回繰り返し行うために，アース用の導線の間にタイマースイッ チを設けた (図 1, 部品番号(13))。このタイマースイッチは, 図 4 に示寸ようにアース時間 te と非アース時間 th を任 意に設定でき，これを交互に連続して切り替えることができる. なお，スイッチのオン・オフを $\mathrm{n}$ 回行う総時間が粉 砕加工時間となるよう設定する.

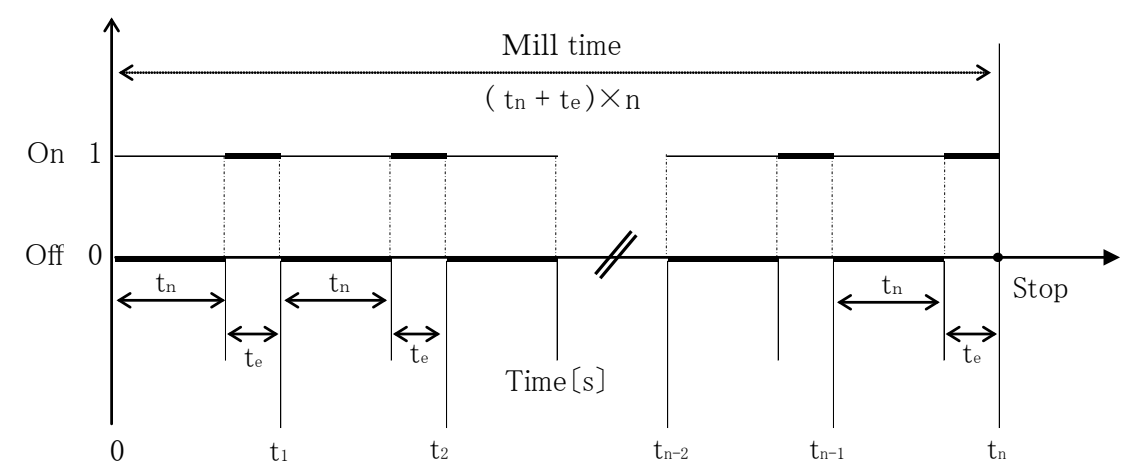

Fig.4 Timechart of switch

\section{$2 \cdot 3 \cdot 3$ 実験時の設定事項}

運転仕椂は表 1 , 原料は乾燥茶葉（一般細菌数 25000 個 $/ \mathrm{g}$ ) を用い, 粉砕加工時間 42 分, te と t $の$ 比を $1: 2$ に設 定し, 非アース・アース回数 $\mathrm{n} を 7,21,28$ とした場合の細菌数の減少率を調査した.

\section{$2 \cdot 3 \cdot 4$ 実験結果}

実験結果を表 4 に示寸．表中の $\mathrm{K}$ は粉砕加工終了後の総減少率，P は $\mathrm{P}=\mathrm{K}^{1 / \mathrm{n}}$ とした場合の減少率である．この結果 から非アース・アース回数を増やすことによって総減少率が減少することがわかる．このことから減菌現象は電荷・ 静電圧の変動によって継続し, 減菌効果は非アース・アース回数に比例すると考えられる. 
Table 4 Decrease ratio of general bacterias

\begin{tabular}{|c|c|c||c|c|c|}
\hline $\begin{array}{c}\text { Sycle time } \\
{[\mathrm{min}]}\end{array}$ & $\begin{array}{c}\text { te } \\
{[\mathrm{sec}]}\end{array}$ & $\begin{array}{c}\mathrm{tn} \\
{[\mathrm{sec}]}\end{array}$ & $\mathrm{n}$ & $\mathrm{K}$ & $\mathrm{P}$ \\
\hline 6 & 120 & 240 & 7 & $1 / 78$ & $1 / 1.856$ \\
\hline 2 & 40 & 80 & 21 & $1 / 196$ & $1 / 1.286$ \\
\hline 1.5 & 30 & 60 & 28 & $1 / 214$ & $1 / 1.214$ \\
\hline
\end{tabular}

\section{$2 \cdot 3 \cdot 5$ 考察}

電圧は二点間の電位の差である. 静電圧測定器による電圧は一点を大地（電位零）としているので，もう一点（被 測定物）の電位に等しい. 電荷・電位・電界は相関関係にあり, 電荷・電位の変動は電界ベクトルの変化を生じる. このことから次に電界ベクトルの変化によって減菌現象が生じる事象の有無を調べる.

\section{3. 減菌現象の原因}

誘電分極の一種である電子分極(8)に着目寸る．電子分極は原子に外からの電界によりマイナスの電荷をもつ電子・ 電子雲と，プラスの電荷をもつ原子核とが互いに反対方向に力を受けて相対的変位を生じ，原子に電気双極子モ一メ ントを生ずる現象である. 分極が平衡に達してから電界を除くと瞬間に消滅せず漸减し，この時発生する緩和周波数 は可視光線〜紫外線の領域にある.この現象が生じて，減菌現象は紫外線の殺菌作用によるものと推測した.

\section{$3 \cdot 1$ 紫外線の殺菌作用}

紫外線のエネルギーは $4.9 \mathrm{eV}$ と少ないが，励起された DNA (デオキシリボ核酸) ${ }^{(9)}$ は分子内で主として隣接したチ ミン塩基の間に共有結合を生じ，二量体（チミンダイマー）を形成する. チミンダイマーが生じた部分では DNA の 水素結合が前後四塩基にわたって切断されるため, 複製が不可能となる. そのため細胞分裂が阻害されて, 微生物な どを死に至らしめるものと考えている. 紫外線の波長帯は 1 400nm である. 最も殺菌力がある $260 \mathrm{~nm}$ 付近の殺菌力 は太陽光に多く含まれる 350nm に比較して 1600 倍に達する(2).

\section{$3 \cdot 2$ 紫外線の発生確認実験}

実験では紫外線の定性的な検出を試みる. 具体的には蓄光シートを用い, これをミルポット蓋の内側に貼り付け (図 6), 長時間暗室内で放置して, 全く発光の無いことを目視で確認したうえで粉砕稼動し，終了直後暗室内で蓋を外し 発光状況を目視で確認のうえ撮影する. 主に紫外線を蓄光して可視光を発する蓄光材の特性から, 発光は紫外線発生 の証拠と考えられる. 使用した畜光材は商品名ルミノバ（B-300）シートで，特性を表 5 ・図 5 に示す.

Table 5 Characteristic and comparison of LumiNova B series

\begin{tabular}{|c|c|}
\hline LumiNova B series & $\begin{array}{l}\text { LumiNova } \\
(\mathrm{B}-300)\end{array}$ \\
\hline Chemical Identity & $\begin{array}{l}\mathrm{CaAl}_{2} \mathrm{O}_{4}: \mathrm{Eu}, \mathrm{Nd}+ \\
\mathrm{Sr}_{4} \mathrm{Al}_{14} \mathrm{O}_{25}: \mathrm{Eu}, \mathrm{Dy}\end{array}$ \\
\hline Body color & Light Yellowish White \\
\hline Av.Particle Size & $30 \mu \mathrm{m}$ \\
\hline Excitation Wave Length & 200-450nm \\
\hline Emission Wave Length & $450 \mathrm{~nm}$ \\
\hline Afterglow Brightness ${ }^{(1)}$ & $\doteqdot 135 \mathrm{mcd} / \mathrm{m}^{2}$ \\
\hline Afterglow Extinction ${ }^{(2)}$ & $>1,000$ min. \\
\hline Excitation Time ${ }^{(3)}$ & $\sim 30 \mathrm{~min}$ \\
\hline Light Fastness ${ }^{(4)}$ & $>1,000$ hours \\
\hline Chemical Stability & Excellent \\
\hline Specific Gravity ${ }^{(5)}$ & 3.3 \\
\hline
\end{tabular}

(1) Brightness after 10 minutes excitation with Xe light of 1000lux for 5 minutes.

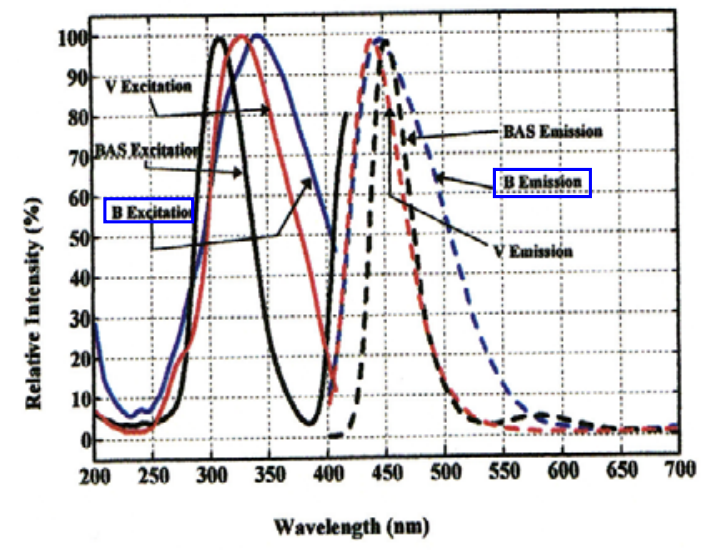

Fig.5 Wave lengh of excitation and emition

(2) Time to decrease the afterglow to $0.32 \mathrm{mcd} / \mathrm{m} 2$ when excited with above condition.

(3) Time required for saturation with Xe light at 1000 lux.

(4) Time to drop the initial afterglow brightness by $20 \%$ after irradiation with $300 \mathrm{~W}$ high pressure mercury lamp. (Accelerated light fastness test)

(5) In powder form 


\section{$3 \cdot 3$ 実験結果}

実験では，粉砕加工時間 15 分, $\mathrm{t}=60$ 秒・ te $=30$ 秒で非アース・アース回数 $\mathrm{n}=10$ に設定した. 図 7 に示すように, 粉砕加工後のルミノーバシートからの発光が確認された. 粉砕加工中に紫外線が発生していることが実証されたこと から, 減菌現象の原因は紫外線であると考えられる.

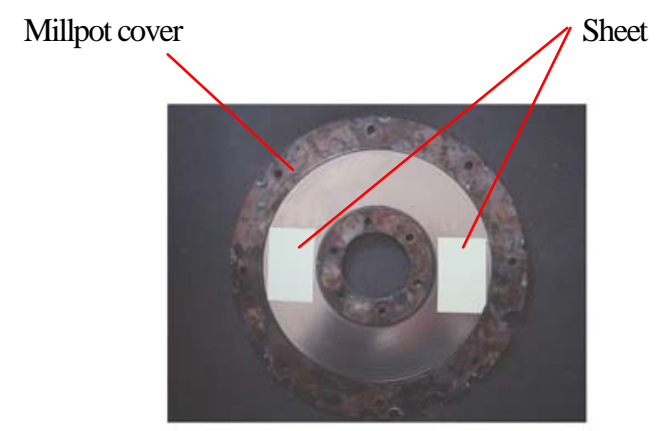

Fig.6 Luminova sheet inside of mill pot cover

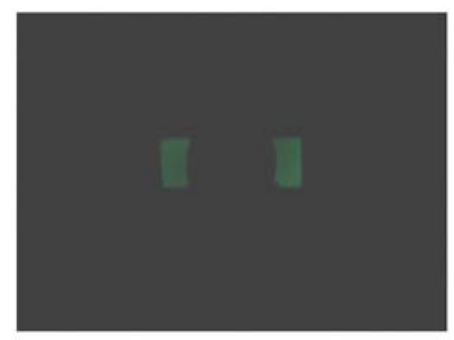

Fig.7 Emission of Luminova(B-300)

\section{4 考察}

$2 \cdot 2 \cdot 1$ の実験で抹茶の静電圧は高くなることから，局所の高電界により絶縁破壊が生じ，無声放電・コロナ放電を 発生してミルポット内部酸素のオゾン化が推測される. 紫外線も酸素をオゾン化する. オゾンは強力な酸化力によっ て殺菌 ${ }^{(10)}$ することが知られている. オゾンの毒性は濃度 $1 \mathrm{ppm}$ で不快, 鼻・喉の刺激, 5〜10ppm で呼吸困難, 肺水 腫, 脈拍増加を起こす ${ }^{(11)}$. オゾンの有無を調べるため毒性に十分注意して粉砕加工直後にミルポットの蓋を開け、臭 いを調査したが，オゾン特有の刺激性は感じられなかった. オゾンガス殺菌では而熱性芽胞菌に対して濃度 100ppm の場合，1〜2 時間の処理時間では殺菌効果は認められないこと ${ }^{(12)}$ が知られている. そこでオゾン化の原因物質であ る酸素を排除する目的でミルポット内に窒素ガスを封入し, 粉砕加工時間 30 分, te $=30$ 秒, tn $=60$ 秒, $\mathrm{n}=20$ に設定

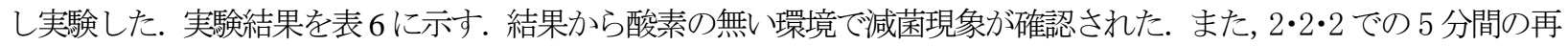
粉砕で, 短時間の減菌現象から, 減菌現象の原因はオゾンではないと考えられる.

Table 6 Number of bacteria

\begin{tabular}{|l|c|c|}
\hline & Number of general bacteria/g & Electrostatics maxvoltage [KV] \\
\hline Tea leaves & 420 & 0 \\
\hline Tea powder & 0 (Did not detect) & -31.5 \\
\hline
\end{tabular}

Means of bacteriological inspection. Standard plate count

Inspectional place.Laboratory of Public Health and Enviromental Chemistry, Kyoto Biseibutu Kenkyusho

$3 \cdot 3$ の実験でのルミノーバからの発光強度から光源のエネルギ一を試算する. 可視限界光度 $0.3 \mathrm{mcd}$ （メーカー提供 值), 光源から人間の睲孔間の距離 $0.3 \mathrm{~m}$, 睲孔直径 $0.7 \mathrm{~cm}$ から人間の睲孔を見込む立体角を約 $4.2 \times 10^{-4}$ ステラジアン とする. また可視不可になるまでの時間は約 120 秒であるが，放出強度は指数関数的に減衰するのが常識的であるの で発光時間を少なく見積り 30 秒とする. ルミノーバシートのエネルギ一変換効率を $100 \%$ とす. 光源エネルギーE

$[\mathrm{J}]$ ，立体角 $\theta$ 〔sr]，発光時間 Dt〔sec〕の関係は(2)式で表せる.

$$
\mathrm{E}=\frac{1}{681} \times \mathrm{cd} \times \theta \times \mathrm{Dt}
$$

$\mathrm{cd}=0.3 \times 10^{-3}, \quad \theta=4.2 \times 10^{-4}, \mathrm{Dt}=30, \mathrm{leV}=1.6 \times 10^{-19} \mathrm{~J}$ から $\mathrm{E} \fallingdotseq 3.5 \times 10^{10} \mathrm{eV}$ である. これは柴外線エネルギー $4.9 \mathrm{eV}$ (波長 $260 \mathrm{~nm}$ ）の約七億倍に相当する. この試算から光源エネルギー・粉体からの紫外線エネルギーは十分に殺 菌できる量と考えられる.

電子分極に起因する紫外線発生には，柴外線領域の高い電界変動・振動が必要であるが(13)，これを可能にしている のがバッチ型垂直回転ボールミル特有の粉砕機構であると推測される. 


\section{4. 乾燥微粉末食材の殺菌実験}

バッチ型垂直回転遊星ボールミルの粉砕加工中における紫外線の発生が乾燥微粉末食材・誘電体からであれば, 乾 燥した細菌表面・きょう膜・細胞壁 ${ }^{(14)}$ からも発生する可能性があり，効果的な殺菌が期待できる．このことを検証す るために多数の一般細菌・大腸菌を含む複数の乾燥粉末食材 (含水率 $5 \%$ 未満) に適用して実験を行った. 運転仕様 は表 1 で, $\mathrm{tn}=60$ 秒, $\mathrm{te}=30$ 秒に設定した場合の粉砕加工前後の食材の細菌数を表 7 に示寸. 表 7 に示すように, い ずれの乾燥粉末食材（500gミミルポッ）においても一般細菌・大腸菌に大きな減菌現象が確かめられた.

Table 7 Sterilization result

\begin{tabular}{|l|r|r|r|r|r|r|}
\hline \multirow{2}{*}{ Raw material } & \multirow{2}{*}{$\mathrm{n}$} & \multicolumn{2}{|c|}{ Number of general bacteria/g } & \multicolumn{2}{c|}{ Number of colon bacteria group/g } \\
\cline { 3 - 7 } & & $\begin{array}{c}\text { Before the } \\
\text { processing }\end{array}$ & $\begin{array}{c}\text { After the } \\
\text { processing }\end{array}$ & \multicolumn{1}{c|}{$\begin{array}{c}\text { Before the } \\
\text { processing }\end{array}$} & $\begin{array}{c}\text { After the } \\
\text { processing }\end{array}$ \\
\hline Silkworm powder & 45 & 2100000 & 670 & $<1 / 1000$ & 150000 & Did not detect \\
\hline Garlic powder & 40 & 500000 & 220 & $<1 / 1000$ & Did not detect & Did not detect \\
\hline Fcoydan powder & 40 & 1600000 & 1300 & $<1 / 1000$ & 45000 & Did not detect \\
\hline Herb powder & 25 & 15000 & Did not detect & 0 & 2300 & Did not detect \\
\hline Denhichi carrot powder & 30 & 54000 & 1100 & $1 / 50$ & 23000 & Did not detect \\
\hline Papaya powder & 50 & 4100000 & 860 & $<1 / 1000$ & 430000 & Did not detect \\
\hline
\end{tabular}

Means of bacteriological inspection. Standard plate count

Inspectional place.Laboratory of Public Health and Enviromental Chemistry, Kyoto Biseibutu Kenkyusho

\section{5. 詰 言}

バッチ型垂直回転遊星ボールミルを用いた乾燥茶葉微粉研殺菌・乾燥微粉末食材殺菌装置を開発することができた. 得られた結果は以下の通りである.

(1) バッチ型垂直回転遊星ボールミルの粉砕加工中にミルポット（ミルポット内の乾燥粉末食材）の非アースとアースを 繰り返すことによって，非加熱殺菌が可能である. 非アース・アース回数が多いほど殺菌効果が大きくなる.

（2）殺菌は, 粉砕加工中に乾燥粉末食材加ら自動的に発生寸る紫外線によるものであると推定される. また，この紫外線 は電子分極が漸减する際に発生する紫外線であると推定できる.

(3) 各種の乾燥粉末食材における殺菌効果は $99 \%$ 以上が可能であり, 実用に適応できる.

\section{6. 今後の課題}

紫外線のスペクトルを測定すること. そして殺菌力の最も強、紫外線（波長 $260 \mathrm{~nm}$ 付近）を最も多量に発生する機 構の開発・改良・運転条件の最適化を試みる必要がある.これにより短時間殺菌と食品品質に及ぼす影響をより少な く出来る.

\section{謝 辞}

（社）京都微生物研究所のご協力（食品衛生法に関する資料提供，菌検出方法の説明，細菌検查報告）に感謝と御 礼を申し上げます。

\section{参考文献}

（1）サイエンスフォーラム，“ガンマー線照射装置とシステム”，殺菌・除菌実用便覧，第一版(2000), pp.198-206.

（2）サイエンスフォーラム，“紫外線照射装置”，殺菌・除菌実用便覽，第一版(2000), pp.153-161.

(3) 三菱総合研究所, “食品の放射線照射に関寸る世界各国・国際機関の規制及びその運用状況の調査”, 食品への放射線照射についての科学的知見のとりまとめ業務報告書, 厚生労働省 $\mathrm{HP}(2010)$ http://www.mhlw.go.jp/topics/bukyoku/iyaku/syoku-anzen/housya/houkokusho.html（参照日 2011 年5月 31 日）。

（4）厚生労働省，“第一食品， B食品の一般製造，加工及調理基淮”，食品，添加物等の規格基隻，厚生省告示第 370 号(1959) 
（5）日本食品衛生学会, “清凉飲料成分規格基準”, 食品衛生学杂隹誌, Vol50, No.1(2009), p.24.

(6) 大林康二, “電荷と静電場, 電位”, 電磁気学, 共立出版, 第一版(1997), pp.1-44.

（7）藤田浩三，殺菌方法及粉砕殺菌装置，日本国特許第 3919773(2007)

(8) 平井平八郎, 大石嘉雄, 成田賢仁, 安藤慶一, 家田正之, 渋川圭弘, “誘電体の誘電分極現象”, 大学課程電気電子材料, オーム社, 改題第一版(2001), pp.1-6.

(9) J.David.Rown, “核酸”，ローン生化学，医学書院，第一版(1991), pp.665-701.

(10) サイエンスフォーラム“オゾン殺菌装置の理論技術”，殺菌・除菌実用便覧，第一版(2000), p.257

(11) サイエンスフォーラム “オゾンの毒性と安全基準”，殺菌・除菌実用便覧，第一版(2000), p.263

(12) サイエンスフォーラム “オゾンガスによる而熱性芽胞菌の殺菌効果”, 殺菌・除菌実用便覧, 第一版(2000), p.258

(13) 小出昭一郎, “光電効果と光子, コンプトン効果”, 現代物理学, 東京大学出版会, 第3 刷(1995), pp.48-49.

(14) 藤野恒二郎, 秦藤樹, 近藤雅臣, “微生物細胞の生理”, 衛生微生物学, 講談社, 第 6 刷(1980), pp.15-50. 